\title{
Original/Otros
}

\section{Cadmium and lead levels consumed by patients with oral hospital diets prescriptions}

\author{
Júlia S. Manzoli de Sá1, Isabela C. Fernandes ${ }^{1}$, Daniele C.F. Moreira ${ }^{1}$, Raquel F. Milani², \\ Marcelo A. Morgano ${ }^{2}$ and Késia Diego Quintaes ${ }^{1}$ \\ ${ }^{\prime}$ Ouro Preto Federal University (UFOP). School of Nutrition. Ouro Preto. Minas Gerais. Brazil. \\ ${ }^{2}$ Institute of Food Technology (ITAL). Center of Foods Science and Quality. Campinas. São Paulo. Brazil.
}

\begin{abstract}
Introduction: The levels of cadmium $(\mathrm{Cd})$ and lead $(\mathrm{Pb})$ in foods should be monitored as a function of health risks.

Objective: To evaluate $\mathrm{Cd}$ and $\mathrm{Pb}$ levels in oral hospital diets and in an oral food complement (OFC) according to their respective consumption by patients, and to estimate the patient's exposition risk.

Methods: The levels of $\mathrm{Cd}$ and $\mathrm{Pb}$ were determined by ICP-OES in samples of regular, blend, soft and renal diets and OFC, collected on 6 weekdays. About 14.3\% of the diets and OFC served were analyzed.

Results and Discussion: 163 patients participated, with mean weights and ages of $62.7 \mathrm{~kg}$ and 56.5 years, respectively, the majority being men $(59.5 \%)$. The mean $\mathrm{Cd}$ content consumed was greater for men fed the regular and blend diets and similar amongst the sexes for the soft diet. The consumption of $\mathrm{Cd}$ (max. $21.02 \mu \mathrm{g} / \mathrm{day}$ ) was below the provisional tolerable monthly intake (PTMI). The mean $\mathrm{Pb}$ ingested (max. $199.49 \mu \mathrm{g} /$ day) was similar amongst the sexes. The soft diet showed the highest $\mathrm{Pb}$ content in September/2010, whereas the other showed no variation according to season. In September/2010 and January/2011, the soft and regular diets associated with the OFC offered 207.50 and $210.50 \mu \mathrm{g} /$ day of $\mathrm{Pb}$, respectively.

Conclusions: The combination of the diet with the OFC increased the risk of an excessive ingestion of $\mathrm{Pb}$, and the vulnerability of the patients to an excessive exposition to $\mathrm{Pb}$ could be greater due to water and medications. It was concluded that whereas the calculated ingestion of $\mathrm{Cd}$ conformed to the PTMI, the Pb level and ingestion represented a risk to the health of the patients.
\end{abstract}

(Nutr Hosp. 2014;29:196-203)

DOI: 10.3305/nh.2014.29.1.6852

Key words: Inorganic contaminants. Food quality. Food analysis. Food service. Heavy metals. Public health.

Correspondence: Kesia Diego Quintaes.

Ouro Preto Federal University.

School of Nutrition - DENCS.

Campus Morro do Cruzaiero, $\mathrm{s} / \mathrm{n}$.

35400-000 Bauxita. Ouro Preto. MG. Brazil.

E-mail:kesia@enut.ufop.br

Recibido: 16-VII-2013.

Aceptado: 30-IX-2013.

\section{NIVELES DE CADMIO Y PLOMO CONSUMIDOS POR PACIENTES QUE RECIBEN DIETAS HOSPITALARIAS ORALES}

Resumen

Introducción: Los niveles de cadmio $(\mathrm{Cd})$ y plomo $(\mathbf{P b})$ en los alimentos deben ser controlados en función del riesgo para la salud.

Objetivo: Evaluar los niveles de $\mathrm{Cd}$ y $\mathrm{Pb}$ en dietas hospitalarias orales y complemento alimentario oral (OFC) y sus ingestiones por pacientes, con estimativa del riesgo de exposición.

Métodos: Los niveles de $\mathrm{Cd}$ y $\mathrm{Pb}$ se determinaron mediante ICP-OES en muestras de dietas regular, blanda, fluida, renal y OFC, recogidas 6 días non-consecutivos. Fueron analizados $14,3 \%$ de las dietas y OFC servidos.

Resultados y Discusión: 163 pacientes participaron, con pesos y edades medias de $62,7 \mathrm{~kg}$ y 56,5 años, respectivamente, en su mayoría varones $(59,5 \%)$. La media de $\mathrm{Cd}$ consumida fue mayor entre hombres alimentados con dietas regular y fluida y similar entre los sexos para la blanda. El consumo de Cd (máx. 21,2 $\mu \mathrm{g}$ /día) estaba por debajo de la ingesta provisional mensual tolerable (IPMT). El contenido medio de $\mathrm{Pb}$ ingerido fue similar entre sexos (máx. 199,49 $\mu \mathrm{g} /$ día). La dieta blanda mostró mayor contenido de $\mathrm{Pb}$ en septiembre/2010, mientras que las otras no variaron según la temporada. En septiembre/2010 y enero/2011, las dietas regular y blanda asociadas al OFC aportaron 207,50 y $210,50 \mu \mathrm{g} /$ día de $\mathrm{Pb}$, respectivamente.

Conclusiones: La combinación de la dieta con OFC aumentó el riesgo de ingestión excesiva de $\mathrm{Pb}$. La vulnerabilidad de los pacientes a una exposición excesiva podría ser mayor en función del agua y medicamentos. La ingestión de Cd calculada cumple el IPMT, pero el nivel de Pb y su ingestión representan riesgo para los pacientes.

(Nutr Hosp. 2014;29:196-203)

DOI: 10.3305/nh.2014.29.1.6852

Palabras clave: Contaminantes inorgánicos. Calidad alimentos. Análisis de alimentos. Servicio de alimentación. Metales pesados. Salud pública. 


\section{Abbreviations}

Cd: Cadmium.

FAO/WHO: Food Agriculture Organization/World

Health Organization.

LOD: Limit of detection.

LQD: Limit of quantification.

MERCOSUR: Mercado Comum do Sul (MERCOSUL).

OFC: Oral food complement.

$\mathrm{Pb}$ : Lead.

PTMI: Provisional Tolerable Monthly Intake.

\section{Introduction}

Feeding is one of the main ways by which man is exposed to cadmium $(\mathrm{Cd})$ and lead $(\mathrm{Pb})^{1}$, both being contemplated amongst the main toxic agents detected in the environment. Exposure to these elements is still a principle interest from the public health point of view, since both are considered as inorganic contaminants with an elevated toxicity potential for human health ${ }^{2}$. With the objective of guaranteeing food safety, since 1972 the Joint FAO/WHO Expert Committee on Food Additives has proposed that the ingestion of inorganic contaminants such as $\mathrm{Pb}$ and $\mathrm{Cd}$ be evaluated in foods and diets ${ }^{3}$.

Current MERCOSUL and European Common Market legislations are restrictive with respect to the $\mathrm{Cd}$ and $\mathrm{Pb}$ contents and cover a great number of foods, limiting the $\mathrm{Cd}$ content to up to $0.05 \mathrm{mg} / \mathrm{kg}$ in meats and some fish species and to $3.0 \mathrm{mg} / \mathrm{kg}$ in algae or mollusk-based food supplements. The $\mathrm{Pb}$ content is limited to up to 1.5 and $0.02 \mathrm{mg} / \mathrm{kg}$ in mollusks and liquid milk, respectively ${ }^{4-6}$.

Nevertheless, despite some controversy, studies from various parts of the world have reported the presence of $\mathrm{Cd}$ and/or $\mathrm{Pb}$ in foods such as cereals, meat and animal viscera and in teas, in amounts that could be toxic to man ${ }^{7-10}$. Many of these foods are considered appropriate and integrate hospital diets, such as bread, fish and teas.

One study reported the presence of $\mathrm{Cd}$ in hospital diets with contents of $0.05 ; 0.09 ; 0.12$ and $0.15 \mathrm{mg} / 100$ $\mathrm{g}$ for bread, bread with fried egg, bread with boiled egg and bread with sardines, respectively ${ }^{11}$. It must be emphasized that more than $90 \%$ of hospital patients are fed oral diets ${ }^{12}$, which should be sensorially attractive, nutritionally balanced and present food safety, which includes respecting current limits for contaminants. However there is a lacuna with respect to the mineral contents in oral hospital diets ${ }^{13}$, including those of the contaminants $\mathrm{Pb}$ and $\mathrm{Cd}$.

Thus considering the above and the lacuna of information, the present study aimed to determine the levels of $\mathrm{Cd}$ and $\mathrm{Pb}$ in oral hospital diets with distinct consistencies (regular, blend and soft) and with differentiated proximate compositions (oral diet for patients with chronic renal insufficiency), and in an artisanal oral food complement (OFC). In addition, the respective amounts of $\mathrm{Cd}$ and $\mathrm{Pb}$ consumed by hospitalized patients were evaluated and the exposition risks calculated, using the Provisional Tolerable Monthly Intake (PTMI) as the reference for $\mathrm{Cd}^{14}$.

\section{Material and methods}

\section{Samples}

This study was of an exploratory nature and was carried out in a hospital that is part of the Brazilian National Health Service in the city of Belo Horizonte (MG, Brazil). The $\mathrm{Cd}$ and $\mathrm{Pb}$ contents were studied in four oral hospital diets, three of which were routine diets (regular, blend and soft) and one a modified diet (renal). The menus of each diet covered a period of six weeks (42 days) and were then repeated, and consisted of six meals: breakfast, mid-morning snack, lunch, mid-afternoon snack, dinner and bedtime snack.

Samples were taken in duplicate of each diet and of the OFC on two consecutive weekdays in May 2010, September 2010 and January 2011. On the sampling days, the weight, age and sex of each patient prescribed the diets under study was registered from their medical records. The protocol of the research was approved by the Ethics in Research Committee of the Fundação Mário Penna (CAAE- 0001.0.261.238-11), since it complied with the group of ethical principles that apply to research involving human beings, as established by the Helsinki agreement.

On the days the diets were sampled, two additional units were prepared for the meals making up the menus of interest to the study, in a way similar to that used in the portioning of the meals destined for the patients. The artisanal oral food complement (OFC) was sampled in an identical way.

The samples were taken at the normal times the meals were offered, as also the OFC, and were weighed on an electronic Pluris Top balance (Filizola S.A. Pesagem e Automação, São Paulo, SP, Brazil) with a capacity of $15 \mathrm{~kg}$ and sensitivity of $2 \mathrm{~g}$. Each meal was homogenized in a food multiprocessor with a plastic helix. A homogenous composition was prepared using $10 \%$ of each meal, resulting in a mixture corresponding to the total daily ingestion of each diet. Fifty gram aliquots of these homogenates of each diet and of the OFC were collected, stored in duly identified zip-lock plastic bags and frozen at $-18^{\circ} \mathrm{C}$ until analyzed.

\section{Chemical analysis}

All the reagents used were of analytical grade. High purity deionized water (resistivity of $18.2 \mathrm{M} \Omega \mathrm{cm}$ ) was obtained using a reverse osmosis water purification system. All glassware was maintained in a $20 \%(\mathrm{v} / \mathrm{v})$ $\mathrm{HNO}_{3}$ solution, and washed with high purity water and 
dried before use. The analytical curves for $\mathrm{Cd}$ and $\mathrm{Pb}$ were prepared from a standard solution of these two elements in $5 \%(\mathrm{v} / \mathrm{v}) \mathrm{HCl}$, obtained by diluting a 1,000 $\mathrm{mg} / \mathrm{L}$ standard solution of $\mathrm{Cd}$ and $\mathrm{Pb}$ (Merck, Darmstadt, Germany). The analytical curve was prepared with 5 points and a concentration interval from 0.0025 to $0.5 \mathrm{mg} / \mathrm{L}$ for both $\mathrm{Cd}$ and $\mathrm{Pb}$.

The contaminants $\mathrm{Pb}$ and $\mathrm{Cd}$ were quantified by inductive coupled plasma optical emission spectrometry (ICP OES) using a Varian model Vista MPX spectrometer (Mulgrave, Australia) equipped with a $40 \mathrm{MHz}$ radio frequency source, charge coupled device solid state simultaneous multi-element detector, peristaltic pump, nebulizer chamber and sea spray type nebulizer. The system was controlled by ICP Expert software and used $99.996 \%$ pure liquid argon (Air Liquid, SP, Brazil). The following operational conditions were used for the ICP OES: power, $1000 \mathrm{~W}$; nebulizer flow rate, 0.9 $\mathrm{L} / \mathrm{min}$; argon flow rate and auxiliary gas flow rate, 15 and $1.5 \mathrm{~L} / \mathrm{min}$; integration times and reading times, 10 and $3 \mathrm{~s}$; number of replicates, 3 . The wavelengths used were 214.439 for $\mathrm{Cd}$ and 220.353 for $\mathrm{Pb}$.

The samples were prepared using an adaptation of the methodology of Slavin et al. ${ }^{15}$ Two grams aliquots of the homogenized samples were weighed into $100 \mathrm{~mL}$ beakers and $25 \mathrm{~mL}$ concentrated $\mathrm{HNO}_{3}$ (Merck, Darmstadt, Germany) added to each. After heating for 2 hours on a heating plate at $180^{\circ} \mathrm{C}$, the extract was cooled and 7 $\mathrm{mL} 30 \%$ hydrogen peroxide (Merck, Darmstadt, Germany) added. The extract was heated again at $180^{\circ} \mathrm{C}$ until the volume was reduced to about $10 \mathrm{~mL}$. After cooling again, the digested sample was quantitatively transferred to a $25 \mathrm{~mL}$ volumetric flask containing 5\% $(\mathrm{v} / \mathrm{v}) \mathrm{HCl}$. The blank solutions were prepared in the same way as the samples and the determinations of the $\mathrm{Cd}$ and $\mathrm{Pb}$ present in the diets made in duplicate.

The analytical sensitivity was determined from the limits of detection (LOD) and quantification (LOQ) obtained from 8 measurements of the solutions of 8 analytical blanks fortified with standard solutions of the minerals at concentrations corresponding to half the most dilute point of the analytical curve. The LOD and LOQ were calculated using the following formulae: $\mathrm{LOD}=\mathrm{t}(\mathrm{n}-1) \cdot \mathrm{s}$ and $\mathrm{LOQ}=\bar{X} 10 \mathrm{~s}$, where $t$ is the value on the abscissa $t$ (Student) and $(\mathrm{n}-1)$ the degrees of liberty (calculated for $99 \%$ of confidence), $s$ $=$ the standard deviation of the analyses and $\bar{X}$ the mean of the values for the blanks ${ }^{16}$.

The specificity of the method for the determination and quantification of the contaminants was evaluated from the emission spectra obtained using the ICP OES for each element, and showed the absence of any interference that could compromise the use of the analytical method. The methodology used was selective for both elements at the wavelengths used. The precision of the method was evaluated from the coefficient of variation of 5 analytical repetitions using the same procedure for measurement, analysis, equipment and repetitions in a short space of time. The exactness of the method was evaluated using the recovery test at a level of 0.025 $\mathrm{mg} / \mathrm{kg}$. It was assumed that values below the LOQ were the same as the LOQ in order to calculate the mean concentrations.

\section{Lead and cadmium ingestion}

The study only included patients that were prescribed the regular, blend or soft oral hospital diets on the sampling days. Those prescribed the renal oral diet were not studied as a function of the study logistics. The patients whose food consumption was evaluated were not informed about the study in order to avoid deviations in the analysis.

The distribution of the meals and the OFC to the patients followed the hospital routine, as also their removal with any leftovers. The latter were separated and weighed individually on an electronic Pluris Top balance (Filizola S.A. Pesagem e Automação, São Paulo, SP, Brazil) with a capacity of $1 \mathrm{~kg}$ and sensitivity of $2 \mathrm{~g}$. The mass obtained was recorded, and, when necessary, the weight of the recipients subtracted. The ingestion of $\mathrm{Cd}$ and $\mathrm{Pb}$ by the patients was calculated from the difference in weight between that carried by the diet and by the OFC served to the patient and that found in the respective leftovers.

In order to obtain an estimate of the monthly exposure of the patients to $\mathrm{Cd}$ and $\mathrm{Pb}$, the mean ingestion per sex and diet of the 6 days studied was multiplied by 30 and divided by $60 \mathrm{~kg}$, which represents the theoretical mean weight of an adult ${ }^{3}$. The $\mathrm{Cd}$ and $\mathrm{Pb}$ contents carried by the diets and ingested by the patients were evaluated according to the Codex Alimentarius ${ }^{14}$, that establishes a Provisional Tolerable Monthly Intake (PTMI) for Cd of $25 \mu \mathrm{g} / \mathrm{kg}$ of body weight, no value having been proposed for the safe ingestion of $\mathrm{Pb}$.

\section{Statistical analysis}

The data were analyzed statistically using the software Stata 12.1 for Mac OS (StataCorp 1995-2011). The Shapiro-Wilk test was used to evaluate the normality of the data. The homoscedasticity of the data was evaluated by the Levene test and the differences between the diets with respect to the levels of $\mathrm{Cd}$ and $\mathrm{Pb}$ were evaluated by the Kruskal-Wallis test. Differences of $p<0.05$ were considered statistically significant. The differences between the diets, body weight and sexes with respect to the mean contents of $\mathrm{Cd}$ and $\mathrm{Pb}$ ingested, were evaluated by the student $t$ test.

\section{Results and discussion}

A total of 163 patients were fed the regular, blend and soft diets on the days studied, the majority (59.5\%) being male. With respect to the type of diet prescribed, 
the majority of the patients were fed the regular diet ( $\mathrm{n}$ =97) and regular diet plus OFC $(n=29)$, followed by the blend diet $(n=19)$ and blend diet plus OFC $(n=8)$. The soft diet was the least prescribed $(n=6)$ even when combined with the OFC $(n=4)$.

Whereas the mean age of the men was $59.1 \pm 15.0$ years old, that of the women was $53.8 \pm 13.6(\mathrm{p}<0.05)$. There was no statistically significant difference between the sexes with respect to mean body weight, which was $64.3 \pm 11.6$ and $61.2 \pm 14.4 \mathrm{~kg}$ for the men and women, respectively. The mean weight of the patients was in agreement with the theoretical weight of an adult man $(60 \mathrm{~kg})$ used by the $\mathrm{FAO} / \mathrm{WHO}^{3}$, although when considering the minimum body weight, this was below the theoretical value, with values of 45.0 and $30.0 \mathrm{~kg}$ for men and women, respectively. It is worth mentioning there is an involuntary loss of weight amongst hospitalized patients as a function of time interned, independent of $\operatorname{sex}^{17}$.
The sampling carried out during the study, which contemplated one day for each of the six weeks (42 days) covered by the menus of the oral hospital diets, represented an analysis of $14.3 \%$ of the total composition of each diet served to the hospitalized patients for each of the diets studied and for the OFC. Table I shows the results obtained for the validation parameters of the analytical methodology. The concentrations of $\mathrm{Cd}$ and $\mathrm{Pb}$ were below the limits of quantification (LOQ) in various samples. The analytical curves obtained for both inorganic contaminants studied showed good linearity with a linear correlation coefficient (r) greater than 0.9999 . The precision and exactness of the method were satisfactory for the results obtained.

Table II shows the mean, maximum and minimum values for $\mathrm{Cd}$ and $\mathrm{Pb}$ found in the four diets and in the OFC. The samplings were grouped according to the season collected, the mean value for the two days

\begin{tabular}{|c|c|c|c|c|c|c|}
\hline \multicolumn{7}{|c|}{$\begin{array}{c}\text { Table I } \\
\text { Performance characteristics of the method for determining cadmium }(\mathrm{Cd}) \text { and lead }(\mathrm{Pb}) \text { in the oral diets and artisanal oral } \\
\text { food complement }(\mathrm{OFC})\end{array}$} \\
\hline Element & $\begin{array}{l}\text { Certified } \\
\text { Value } \\
(m g / k g)\end{array}$ & $\begin{array}{l}\text { Measured } \\
\text { Value } \\
(\mathrm{mg} / \mathrm{kg})\end{array}$ & $\begin{array}{c}\text { Recovery } \\
(\%)\end{array}$ & $\begin{array}{l}\text { Precision* } \\
\quad(\%)\end{array}$ & $\begin{array}{c}L O D^{* *} \\
(m g / L)\end{array}$ & $\begin{array}{c}L O Q^{* * * *} \\
(m g / L)\end{array}$ \\
\hline $\mathrm{Cd}$ & 0.025 & $0.0204 \pm 0.0005$ & 82 & 2 & 0.0002 & 0.003 \\
\hline $\mathrm{Pb}$ & 0.025 & $0.023 \pm 0.003$ & 92 & 14 & 0.0007 & 0.006 \\
\hline
\end{tabular}

Note: LOD, limit of detection; LOQ, limit of quantification; $* \mathrm{n}=5 ; * * \mathrm{LOD}=\mathrm{t}(\mathrm{n}-1) * \mathrm{~s} ; * * * \mathrm{LOQ}=$ average of the blanks values $+10 \mathrm{~s} ; \mathrm{t}=T$-test $(\mathrm{p}$ $=0.01) ; \mathrm{s}=$ standard deviation.

\section{Table II}

Average ( \pm standard deviation), minimum and maximum levels of cadmium $(C d)$ and lead $(P b)$ content by the regular $(R)$, blend $(B)$, soft $(S)$, renal $(R n)$ diets and artisanal oral food complement (OFC)

\begin{tabular}{|c|c|c|c|c|c|c|c|}
\hline \multirow[b]{2}{*}{$\begin{array}{l}\text { Sample } \\
\text { times }\end{array}$} & \multirow[b]{2}{*}{ Material } & \multicolumn{3}{|c|}{$C d(\mu g / d a y)$} & \multicolumn{3}{|c|}{$P b(\mu g / d a y)$} \\
\hline & & Average $\pm S D$ & Min. & $\operatorname{Max}$ & Average $\pm S D$ & Min. & Max. \\
\hline \multirow[t]{5}{*}{ May 2010} & $\mathrm{R}$ diet & $21.02^{\mathrm{ax}} \pm 0.35$ & 20.69 & 21.34 & $72.31^{\mathrm{ax}} \pm 18.36$ & 62.07 & 109.63 \\
\hline & B diet & $22.48^{\mathrm{ax}} \pm 1.81$ & 19.72 & 26.29 & $81.42^{\mathrm{ax}} \pm 26.87$ & 65.73 & 127.08 \\
\hline & S diet & $19.37^{\mathrm{ay}} \pm 0.09$ & 19.29 & 19.45 & $68.08^{\mathrm{cx}} \pm 20.17$ & 57.87 & 112.81 \\
\hline & Rn diet & $17.23^{\mathrm{ay}} \pm 0.50$ & 16.76 & 17.69 & $75.56^{\mathrm{ax}} \pm 44.12$ & 50.28 & 160.90 \\
\hline & OFC & $3.22^{\mathrm{a}} \pm 0.04$ & 1.51 & 1.70 & $9.66^{\mathrm{a}} \pm 0.11$ & 4.53 & 5.10 \\
\hline \multirow{5}{*}{ Sep 2010} & $\mathrm{R}$ diet & $14.11^{\mathrm{ax}} \pm 9.44$ & 3.86 & 29.61 & $178.2^{\mathrm{ax}} \pm 122.09$ & 27.87 & 314.26 \\
\hline & $\mathrm{B}$ diet & $15.45^{b x} \pm 7.93$ & 6.74 & 26.17 & $114.53^{\mathrm{ax}} \pm 77.03$ & 50.52 & 244.18 \\
\hline & S diet & $12.04^{\mathrm{ax}} \pm 3.01$ & 7.98 & 16.37 & $186.19^{\mathrm{ax}} \pm 76.15$ & 89.13 & 295.26 \\
\hline & Rn diet & $11.44^{\mathrm{ax}} \pm 4.74$ & 6.72 & 16.8 & $156.10^{\mathrm{ax}} \pm 97.94$ & 48.18 & 274.24 \\
\hline & OFC & $1.88^{\mathrm{b}} \pm 0.31$ & 1.00 & 1.67 & $21.32^{\mathrm{b}} \pm 0.23$ & 5.53 & 13.30 \\
\hline \multirow[t]{5}{*}{ Jan 2011} & $\mathrm{R}$ diet & $20.97^{\mathrm{ax}} \pm 0.60$ & 20.41 & 21.53 & $199.49^{a x} \pm 95.14$ & 61.23 & 297.11 \\
\hline & $\mathrm{B}$ diet & $18.32^{\mathrm{bx}} \pm 3.45$ & 12.94 & 21.57 & $131.95^{\mathrm{ax}} \pm 88.62$ & 58.14 & 281.01 \\
\hline & $\mathrm{S}$ diet & $19.65^{\mathrm{bx}} \pm 1.05$ & 18.67 & 20.63 & $101.72^{b x} \pm 53.40$ & 57.88 & 183.61 \\
\hline & Rn diet & $20.05^{\mathrm{bx}} \pm 0.78$ & 19.32 & 20.78 & $143.07^{\mathrm{ax}} \pm 81.64$ & 62.34 & 268.55 \\
\hline & $\mathrm{OFC}$ & $3.21^{\mathrm{a}} \pm 0.02$ & 1.48 & 1.70 & $14.65^{\mathrm{a}} \pm 14.65$ & 4.44 & 21.31 \\
\hline
\end{tabular}

${ }^{a, b, c}$ Differences $(\mathrm{p}<0.05)$ for the same diet or OFC in distinct sample times (Kruskal-Wallis)

${ }_{x, y, z}$ Differences $(\mathrm{p}<0.05)$ among diets in the same sample time (Kruskal-Wallis) 
studied in each season being indicated. With respect to $\mathrm{Cd}$, the regular diet carried similar mean values in the three times studied, the blend one showed a greater content in may 2010, whereas the soft and renal diets showed their greatest contents in january 2011. In may 2010 the regular and blend diets showed greater contents than the soft and renal diets.

With respect to $\mathrm{Pb}$ the soft diet showed the greatest content in september 2010, followed by january 2011 , with the smallest content in May 2010. The other diets did not show statistically significant variation between the values found for the three seasons. For the same season the values found for $\mathrm{Pb}$ carried by the different diets also showed no significant statistical difference. With respect to the OFC, greater contents of both $\mathrm{Cd}$ and $\mathrm{Pb}$ were detected in september 2010, whereas the quantities were similar in may 2010 and january 2011 (Table II). The $\mathrm{Pb}$ content found in the OFC could be explained in part by the fact that the artisanal formulation used included milk, which can contain reasonable $\mathrm{Pb}$ contents ${ }^{18,19}$.

A study involving the analysis of trace elements in oral hospital diets reported a $\mathrm{Cd}$ content that varied according to the type of meal and its composition. For breakfast the amount oscillated between 0.05 and 0.15 $\mathrm{mg} / 100 \mathrm{~g}$ dry diet, the highest value being observed when fish was including amongst the foods making up the meal. Values for Cd between 0.02 and $0.29 \mathrm{mg} / 100$ $\mathrm{g}$ dry diet were found for the lunch and dinner meals, the higher values occurring when the meals contained meat or fish ${ }^{11}$.

Fish, meat and meat products have been indicated as vehicles of inorganic contaminants such as $\mathrm{Cd}$ and $\mathrm{Pb}$, with significantly different concentrations as a function of the species of fish ${ }^{8,9}$. In january 2011, the regular, blend and renal diets all included fish with shrimp sauce on the dinner menu of one of the days analyzed, showing higher values for $\mathrm{Pb}$ on this occasion as compared to the soft diet $(\mathrm{p}<0.05)$.

The mean contents found for $\mathrm{Cd}$ and $\mathrm{Pb}$ in the OFC varied as a function of the season the diets were sampled. The mean daily amounts of $\mathrm{Cd}$ in the OFC were $3.22,1.88$ and $3.22 \mu \mathrm{g}$ in the months of may 2010, September 2010 and january 2011, respectively. Simi- larly the values for the mean daily content of $\mathrm{Pb}$ carried by the OFC oscillated, giving values of 9.66, 21.32 and $14.65 \mu \mathrm{g}$. The $\mathrm{Cd}$ and $\mathrm{Pb}$ counts found in the $\mathrm{OFC}$ in september 2010 showed statistically significant differences from the values found in the other seasons, being lower than the others for $\mathrm{Cd}$ and higher than the others for $\mathrm{Pb}$. Table III shows the mean total contents found for $\mathrm{Cd}$ and $\mathrm{Pb}$ obtained from the association of the oral hospital diets with the OFC and the respective percent increase caused by the use of the combination with $\mathrm{OFC}$ in the distinct diets for the different seasons under study.

The combination of the OFC with the regular diet presented a relatively stable increase in $\mathrm{Cd}$ for all the seasons sampled, whereas for the blend diet, in january 2011, the association with OFC increased the total $\mathrm{Cd}$ content by approximately $17 \%$. The greatest increase in the $\mathrm{Cd}$ content caused by the association with OFC occurred in the renal diet in may 2010, with an increase of almost $19 \%$ in the contaminant (Table III).

With respect to $\mathrm{Pb}$, the combination of the regular and renal diets with the OFC showed the lowest percent increases in january 2011, being 5.5 and $7.7 \%$, respectively. On the other hand, the association of the soft diet with the OFC resulted in an increase of $18.6 \%$ in the $\mathrm{Pb}$ content in september 2010. The percent increases in the $\mathrm{Pb}$ content caused by the combination of the soft diet with the OFC were relatively stable as a function of the sampling season (Table III).

It should be emphasized that in september 2010 and january 2011 the combinations of the OFC with the soft and regular diets resulted in $\mathrm{Pb}$ contents of 207.51 and $210.53 \mu \mathrm{g} / \mathrm{day}$, respectively. These values bordered on the maximum values for $\mathrm{Pb}$ formerly considered safe by $\mathrm{FAO} / \mathrm{WHO}^{3}$. However, according to Codex Alimentarius, all the oral diets involved in this study showed lead contents that could put the health of the patients at risk ${ }^{14}$.

In addition, the present study did not compute any $\mathrm{Cd}$ or $\mathrm{Pb}$ eventually carried by the water consumed by the patients, which could represent an additional source of these contaminants, even if the water alone was within the maximum limits allowed by current legislation. In the case of $\mathrm{Pb}$, any additional amount ingested via

\section{Table III}

Absolutle and percentile contribution (\%) of the artisanal oral food complement $(O F C)$ in the level of cadmium $(C d)$ and lead $(\mathrm{Pb})$ of the regular $(R)$, blend $(B)$, soft $(S)$ or renal $(R n)$ oral diets in function of the times of sample data collection

\begin{tabular}{|c|c|c|c|c|c|c|c|c|c|c|c|c|}
\hline \multirow{4}{*}{$\begin{array}{l}\text { Diet + } \\
\text { OFC }\end{array}$} & \multicolumn{12}{|c|}{ Sample times } \\
\hline & \multicolumn{4}{|c|}{ May 2010} & \multicolumn{4}{|c|}{ Septiember 2010} & \multicolumn{4}{|c|}{ January 2011} \\
\hline & \multicolumn{2}{|c|}{$C d$} & \multicolumn{2}{|c|}{$\mathrm{Pb}$} & \multicolumn{2}{|c|}{$C d$} & \multicolumn{2}{|c|}{$\mathrm{Pb}$} & \multicolumn{2}{|c|}{$C d$} & \multicolumn{2}{|c|}{$P b$} \\
\hline & ( $\mu g / d a y)$ & $\%$ & ( $\mu g / d a y)$ & $\%$ & ( $\mu g / d a y)$ & $\%$ & ( $\mu g / d a y)$ & $\%$ & ( $\mu g / d a y)$ & $\%$ & ( $\mu g / d a y)$ & $\%$ \\
\hline $\mathrm{R}+\mathrm{OFC}$ & 24.24 & 15.3 & 81.97 & 13.4 & 15.99 & 13.3 & 199.56 & 12.0 & 24.06 & 14.7 & 210.53 & 5.5 \\
\hline $\mathrm{B}+\mathrm{OFC}$ & 25.70 & 14.3 & 91.08 & 11.9 & 17.33 & 12.2 & 135.86 & 18.6 & 21.41 & 16.9 & 142.99 & 8.4 \\
\hline $\mathrm{S}+\mathrm{OFC}$ & 22.59 & 16.6 & 77.74 & 14.2 & 13.91 & 15.6 & 207.51 & 11.4 & 22.74 & 15.7 & 112.76 & 10.8 \\
\hline $\mathrm{Rn}+\mathrm{OFC}$ & 20.45 & 18.7 & 85.22 & 12.8 & 13.32 & 16.4 & 177.42 & 13.7 & 23.14 & 15.4 & 154.11 & 7.7 \\
\hline
\end{tabular}


potable water would increase the exposition to the element to the point of configuring a lack of food safety.

In Brazil a study showed that the lead content of water varied between 3.9 and $5.3 \mu \mathrm{g} / \mathrm{L}$ for mineral water, and was $4.7 \mu \mathrm{g} / \mathrm{L}$ for potable tap water ${ }^{20}$. Considering a maximum consumption of $2 \mathrm{~L}$ of mineral water per day per patient, the contribution to the daily lead consumption would be to the order of 7.8 to $10.6 \mu \mathrm{g}$ in the months of september 2010 and january 2011, respectively. This hypothesis of exposition is also in agreement with the estimate for the daily ingestion of $\mathrm{Pb}$ by adults from the potable water supply, which, according to the data of WHO, presented a mean of 5 $\mu \mathrm{g} / \mathrm{L}$ of $\mathrm{Pb}$, representing a calculated ingestion of $\mathrm{Pb}$ of $10 \mu \mathrm{g} /$ day $^{21}$.

University students in Italy were also considered to show a high potential risk due to the great amounts of $\mathrm{Cd}$ and $\mathrm{Pb}$ ingested in their diets. In this study, an analysis of $\mathrm{Cd}$ and $\mathrm{Pb}$ in the foods and meals served to the students during six days in the months of february and may indicated high levels of $\mathrm{Cd}$ and $\mathrm{Pb}$ in foods such as the bread, meat, pasta and cheeses frequently consumed by the students. On the other hand, foods that they normally consumed less, such as fruits and vegetables, presented low amounts of $\mathrm{Cd}$ and $\mathrm{Pb}^{22}$.

The levels found, especially those of $\mathrm{Pb}$, in the OFC and in the soft and regular diets indicated a need to change the choice of foods making up the diets and the $\mathrm{OFC}$, and maybe with respect to the food handling practices, since there is an eminent risk in exposing hospitalized patients to levels representing toxicity by the consumption of these diets and the OFC. The aggregation of foods containing a certain amount of phytate, such as whole rice, could minimize the degree of exposition to lead, since this favors elimination of the $\mathrm{Pb}$ in the feces ${ }^{23}$, and it has been reported that ovolacto vegetarians present a tendency to a greater elimination of these elements ${ }^{24}$.
With respect to the consumption of $\mathrm{Cd}$ and $\mathrm{Pb}$ by the patients according to their sex and the diet received (regular, blend and soft), it was shown that the mean $\mathrm{Cd}$ content consumed was higher amongst men fed the regular and blend diets, whereas for the soft diet, the mean $\mathrm{Cd}$ content consumed was similar for both sexes. With respect to $\mathrm{Pb}$, the mean content ingested from all the diets was similar for both sexes (Table IV).

For the estimate of the monthly exposition to $\mathrm{Cd}$ (Table V), the values found were always below 25 $\mu \mathrm{g} / \mathrm{kg}$ of body weight, showing that for both sexes, the exposition to $\mathrm{Cd}$ was below the provisional tolerable monthly intake (PTMI). The highest value estimated for the monthly ingestion of $\mathrm{Cd}$ was for the association of the blend diet with the OFC, for both men (8.80 $\mu \mathrm{g} / \mathrm{kg})$ and women $(9.11 \mu \mathrm{g} / \mathrm{kg})$. Recent dietary study in the European population estimates the dietary exposure of Cd ranged from 2.65 (2.57-2.72) to 4.99 (4.62$5.38) \mathrm{g} / \mathrm{kg} / \mathrm{bw} / \mathrm{week}^{25}$. There is no PTMI in the case of $\mathrm{Pb}$ and the calculation of the estimated monthly exposition according to sex, indicated the values shown in Table V. The blend diet associated with the OFC provided the greatest exposition for women $(60.84$ $\mu \mathrm{g} / \mathrm{kg}$ ) and the regular diet associated with the OFC for men $(61.96 \mu \mathrm{g} / \mathrm{kg})$.

It is worth highlighting that patients with a low body weight would be even more vulnerable to presenting a greater risk of intoxication by $\mathrm{Cd}$ and $\mathrm{Pb}$ as compared to patients with a body weight equal or higher than the theoretical value used in the evaluations of toxicological safety $(60 \mathrm{~kg})$. There is evidence that as a function of the pathology and the time in hospital, there is an involuntary loss of weight $(8.6 \pm 6.4 \mathrm{~kg})$ amongst interned patients, ${ }^{17}$ being the male a factor mostly closely related with the length of hospital $\operatorname{stay}^{26}$. In the present study, males are the majority among hospitalized patients $(59,5 \%)$ and female and male patients were found with minimum weights of 30.0 and $45.0 \mathrm{~kg}$,

\begin{tabular}{|c|c|c|c|c|c|c|c|}
\hline \multicolumn{8}{|c|}{$\begin{array}{c}\text { Table } \mathbf{I V} \\
\text { Average ( } \pm \text { standard deviation), minimum and maximum levels of cadmium }(C d) \text { and lead }(P b) \text { ingested by female }(F) \\
\text { and male }(M) \text { hospitalized patients by the oral diet type consumed }\end{array}$} \\
\hline \multirow{2}{*}{$\begin{array}{l}\text { Diets } \\
\text { types }\end{array}$} & \multirow[b]{2}{*}{ Sex } & \multicolumn{3}{|c|}{$C d(\mu g / d a y)$} & \multicolumn{3}{|c|}{$P b(\mu g / d a y)$} \\
\hline & & Average $( \pm S D)$ & Min. & $\operatorname{Max}$ & Average $( \pm S D)$ & Min. & Max. \\
\hline Regular & $\begin{array}{l}\mathrm{F}(\mathrm{n}=43) \\
\mathrm{M}(\mathrm{n}=54) \\
\quad P\end{array}$ & $\begin{array}{l}13.13^{\mathrm{a}} \pm 0.65 \\
15.17^{\mathrm{b}} \pm 0.61 \\
0.02\end{array}$ & $\begin{array}{c}6.08 \\
3.6\end{array}$ & $\begin{array}{l}21.02 \\
21.02\end{array}$ & $\begin{array}{l}110.34^{\mathrm{a}} \pm 8.41 \\
123.92^{\mathrm{a}} \pm 7.25 \\
0.22\end{array}$ & $\begin{array}{l}23.61 \\
25.26\end{array}$ & $\begin{array}{l}199.49 \\
199.49\end{array}$ \\
\hline Blend & $\begin{array}{l}\mathrm{F}(\mathrm{n}=12) \\
\mathrm{M}(\mathrm{n}=7) \\
\quad P\end{array}$ & $\begin{array}{l}11.87^{\mathrm{a}} \pm 1.35 \\
17.60^{\mathrm{b}} \pm 1.17 \\
0.01\end{array}$ & $\begin{array}{c}3.54 \\
13.83\end{array}$ & $\begin{array}{l}19.32 \\
22.48\end{array}$ & $\begin{array}{c}73.08^{\mathrm{a}} \pm 8.97 \\
87.73^{\mathrm{a}} \pm 9.57 \\
0.3\end{array}$ & $\begin{array}{c}25.5 \\
62.21\end{array}$ & $\begin{array}{c}110.7 \\
131.95\end{array}$ \\
\hline Soft & $\begin{array}{c}\mathrm{F}(\mathrm{n}=4) \\
\mathrm{M}(\mathrm{n}=2) \\
P\end{array}$ & $\begin{array}{c}10.09^{\mathrm{a}} \pm 2.18 \\
15.22^{\mathrm{a}} \pm 4.05 \\
0.28\end{array}$ & $\begin{array}{c}4.13 \\
11.16\end{array}$ & $\begin{array}{l}14.59 \\
19.28\end{array}$ & $\begin{array}{c}79.63^{\mathrm{a}} \pm 28.78 \\
62.79^{\mathrm{a}} \pm 4.98 \\
0.71\end{array}$ & $\begin{array}{c}38.74 \\
57.8\end{array}$ & $\begin{array}{c}164.59 \\
67.77\end{array}$ \\
\hline
\end{tabular}

a,b differences $(\mathrm{p}<0.05)$ among sex for the ingested level of $\mathrm{Cd}$ or $\mathrm{Pb}$ (student $t$ test). 
Table V

Estimate of monthly ingestion of cadmium $(\mathrm{Cd})$ and lead $\mathrm{P}(\mathrm{P})$ among female and male hospitalized patients who receive oral diets (regular, blend, soft) only or with artisanal oral food complement (OFC)

\begin{tabular}{lccccc}
\hline & \multicolumn{2}{c}{$C d$} & & \multicolumn{2}{c}{$P b$} \\
\cline { 2 - 3 } \cline { 6 - 7 } Diets types and OFC & $\begin{array}{c}\text { Female } \\
(\mu g / \mathrm{kg})\end{array}$ & $\begin{array}{c}\text { Male } \\
(\mu g / \mathrm{kg})\end{array}$ & & $\begin{array}{c}\text { Female } \\
(\mu g / \mathrm{kg})\end{array}$ & $\begin{array}{c}\text { Male } \\
(\mu g / \mathrm{kg})\end{array}$ \\
\hline Regular & 6.56 & 7.58 & & 55.17 & 60.86 \\
Regular + OFC & 7.18 & 7.58 & & 59.81 & 61.96 \\
Blend & 5.93 & 8.60 & & 36.54 & 43.86 \\
Blend + OFC & 9.11 & 8.80 & & 60.84 & 47.92 \\
Soft & 5.04 & 7.61 & & 39.81 & 31.39 \\
Soft + OFC & 8.03 & 6.24 & & 32.78 & 21.48 \\
\hline
\end{tabular}

respectively. It is known that a lower body mass results in a greater concentration of $\mathrm{Pb}$ in the organism, even if one considers the possibility of reduced food ingestion ${ }^{1}$, increasing the vulnerability of the patients to $\mathrm{Pb}$ in relation to their healthy pairs.

Another aggravating factor is that hospitalized patients are subjected to the use of medication, and these, in addition to interfering with the absorption mechanisms and processes ${ }^{27}$, could also represent additional sources of ingestion of these contaminants. ${ }^{28} \mathrm{~A}$ study of the $\mathrm{Cd}$ and $\mathrm{Pb}$ contents of 34 syrups commercialized in Nigeria reported that 98 and 60\%, presented $\mathrm{Cd}$ and $\mathrm{Pb}$ respectively, with values of from 0.01 to 2.45 and from 0.01 to $1.08 \mathrm{mg} / \mathrm{L}$ for $\mathrm{Cd}$ and $\mathrm{Pb}$, respectively ${ }^{28}$.

In addition, the estimates of exposition reported in the present paper were based on the mean total concentrations of $\mathrm{Cd}$ and $\mathrm{Pb}$ carried by the diets analyzed, associated or not with the OFC, the estimated value being lower than the true value, since it did not include the contents of these elements in the water consumed by these patients. The lacuna of data concerning these inorganic contaminants in oral hospital diets limits a comparison with other studies, and at the same time, indicates the relevance of this exploratory study, even though it was carried out in a single hospital. Ingestion (water, food and soil) responds for $99 \%$ of the $\mathrm{Pb}$ consumed by man, and a reduction of the $\mathrm{Pb}$ content in diets is recommended as a more efficient measure to reduce the $\mathrm{Pb}$ levels in the blood of human populations ${ }^{1}$.

\section{Conclusions}

Whereas the ingestion of $\mathrm{Cd}$ complied with the PTMI, that of $\mathrm{Pb}$ represented a risk to the health of the patients. The association of the diet with the OFC increased the chance of a health risk to the patient, especially with respect to the ingestion of $\mathrm{Pb}$. Water and medication represent additional sources which should be investigated, and the latter could interfere with the digestive and absorptive processes. In addi- tion, although the mean weight of the patients was close to the theoretical value used in the evaluation of health risks, in practice the hospitalized patients could weigh less than this, increasing the possibility of intoxication by these inorganic contaminants. It is important to monitor all the possible sources of contamination of foods by $\mathrm{Cd}$ and $\mathrm{Pb}$ and promote the selection of foods and preparations containing lower contents of these elements and the inclusion of foods on the menu that contain constituents that minimize the risk of intoxication. The food toxicology quality control in the hospital food service must be improved.

\section{Acknowledgements}

The authors are grateful to Isabela B. Cerqueira, Ana Flávia L. Gontijo, Karine A. Louvera Silva and Maria Arlene Fausto for help with sample data collection and analysis, to Fundação de Amparo à Pesquisa do Estado de Minas Gerais (FAPEMIG) for the grant to Moreira, DFC. Quintaes, KD and Morgano, MA also are grateful to Conselho Nacional de Desenvolvimento Científico e Tecnológico (CNPq) for their researchers grants $(237331 / 2012-8)$.

\section{Funding}

This work was supported by the Fundação de Amparo à Pesquisa do Estado de Minas Gerais (FAPEMIG), financial support APQ 01558-09 and APQ-01007-10.

\section{References}

1. Pizzol M, Thomsen M, Andersen MA. Long-term human exposure to lead from different media and intake pathways. Sci Total Environ 2010;408:5478-88.

2. Wang G, Fowler BA. Roles of biomarkers in evaluating interactions among mixtures of lead, cadmium and arsenic. Toxicol Appl Pharmacol 2008;233:92-9.

3. FAO/WHO (Food Agriculture Organization/World Health Organization). Evaluation of certain food additives and contaminants: seventy-third report of the Joint FAO/WHO Expert Committee on Food Additives. WHO Technical Report Series. n. 960; 2011. Available from: <whqlibdoc.who.int/trs/WHO_ TRS_960_eng.pdf.> Accessed 05 Aug 2012.

4. Commission Regulation (EU) 2006/1881/EC of 19 December 2006 setting maximum levels for certain contaminants in foodstuffs. Official J European Union L 2006;364:5-24.

5. Commission Regulation (EU) No 420/2011 of 29 April 2011 amending Regulation (EC) No 1881/2006 setting maximum levels for certain contaminants in foodstuffs Text with EEA relevance. Official J European Union L 2011;111:3-6.

6. MERCOSUL (Mercado Comum do Sul). Resolução GMC n. 012/2011. Regulamento técnico MERCOSUL sobre limites máximos de contaminantes inorgânicos em alimentos, 2011. Available from: <http://www.mercosur.int/innovaportal/v/ 3187/1/secretaria /resoluc\%C3\%B5es_2011>. Accessed 30 Jul 2012.

7. Hernández-Martínez R, Navarro-Blasco I. Estimation of dietary intake and content of lead and cadmium in infant cereals marketed in Spain. Food Control 2012;26:6-14. 
8. Castro-González MI, Méndez-Armentab M. Heavy metals: Implications associated to fish consumption. Environ Toxicol Pharmacol 2008;26:263-71.

9. Vieira C, Morais S, Ramos S, Delerue-Matos C, Oliveira MBPP. Mercury, cadmium, lead and arsenic levels in three pelagic fish species from the Atlantic Ocean: Intra- and interspecific variability and human health risks for consumption. Food Chem Toxicol 2011;49:923-32.

10. Karak T, Bhagat RM. Trace elements in tea leaves, made tea and tea infusion: A review. Food Res Int 2010;43:2234-52.

11. Akinyele IO, Osibanjo O. Levels of some trace elements in hospital diets. Food Chem 1982;8:247-51.

12. Correia MITD, Campos ACL. Prevalence of hospital malnutrition in Latin America: the Multicenter ELAN Study. Nutrition 2003;19:823-25.

13. Moreira DCF, Manzoli de Sá JS, Cerqueira IB, Oliveira APF, Morgano MA, Amaya-Farfan J, Quintaes KD. Mineral inadequacy of oral diets offered to patients in a Brazilian hospital. Nutr Hosp 2012;27:288-97.

14. Codex Alimentarius Commission. Codex Alimentarius Commission Procedural Manual. 20 ${ }^{\text {th }}$ ed; 2011. Available from: $<f t p$ ://ftp.fao.org/codex/Publications/ProcManuals/Manual_20e. pdf.> Accessed 02 Aug 2012.

15. Slavin S, Petersen, GE, Lindhal PC. Determination of heavy metals in meats by atomic absorption spectroscopy. At Absorpt Newsletter 1975;14:57-9.

16. INMETRO (Instituto Nacional de Metrologia, Qualidade e Tecnologia). Orientação sobre validação de métodos analíticos - DOC CGRE-008. Brasília, DF; 2010.

17. Wu J-M, Lin M-H, Peng L-N, Chen L-K, Hwang S-J. Evaluating diagnostic strategy of older patients with unexplained unintentional body weight loss: A hospital-base study. Arch Gerontol Geriatr 2011;53:51-4.
18. Santos EE, Lauria DC, Porto da Silveira CL. Assessment of daily intake of trace elements due to consumption of foodstuffs by adult inhabitants of Rio de Janeiro city. Sci Total Environ 2004;327:69-79.

19. Rahimi E. Lead and cadmium concentrations in goat, cow, sheep, and buffalo milks from different regions of Iran. Food Chem 2013;136:389-91.

20. Martins VL, Galvão RKH, Araújo MCU, Gaião EN. WaveletBased determination of $\mathrm{Cu}$ and $\mathrm{Pb}$ in water samples using potentiometric stripping analysis with a Lab-Made potentiostat. J Braz Chem Soc 2009;20:1561-4.

21. WHO (World Health Organization). Lead in drinking-water. Background document for development of WHO guidelines for drinking-water quality; 2011.

22. Alberti-Fidanza A, Burini G, Perriello G. Trace elements in foods and meals consumed by students attending the faculty cafeteria. Sci Total Environ 2002;287:133-40.

23. Cúneo F, Farfan JA, Morgano MA. Dietary phytates protect the rat against lead toxicity. Int J Food Agric Environ 2006;4:45-9.

24. Vahter M, Johansson G, Ảkesson A, Rahnster B. Faecal elimination of lead and cadmium in subjects on a mixed and a lactovegetarian diet. Food Chem Toxicol 1992;30:281-7.

25. Ferrari P, Arcella D, Heraud F, Cappé S, Fabiansson S. Impact of refining the assessment of dietary exposure to cadmium in the European adult population. Food Addit Contam Part A Chem Anal Control Expo Risk Assess 2013;30:687-97.

26. Valente da Silva, HG, Santos SO, Silva NO, Ribeiro, FD, Josua LL, Moreira ASB. Evaluación nutricional asociada con la estancia hospitalaria. Nutr Hosp 2012;27:542-7.

27. Manzi SF, Shannon M. Drug Interactions - a review. Clin Ped Emerg Med 2005;6:93-102.

28. Orisakwe OE, Nduka JK. Lead and cadmium levels of commonly administered pediatric syrups in Nigeria: A public health concern? Sci Total Environ 2009;407:5993-96. 